\title{
Teachers' Competency in Integration of Information Communication Technology in Early Learning in Bungoma County, Kenya
}

\author{
Douglas Patrick Barasa \\ Department of Curriculum Instruction and Educational Media, School of Education, Moi University \\ Prof. Peter L. Barasa \\ Department of Curriculum Instruction and Educational Media, School of Education, Moi University \\ Prof. Carolyne Omulando \\ Department of Language and Literature Education, School of Education and Social Sciences, Alupe University \\ College
}

\begin{abstract}
Integrating Information Communication Technology into curricula with the intent of positively influencing teaching and learning has been in a state of evolution over the past 20 years. The purpose of the study was to analyse teachers' competency in integration of ICT, into teaching and learning in early learning in Bungoma County, Kenya. The study was guided by Technological Pedagogical Content Knowledge Framework (TPACK) by Punya Mishra and Matthew J. Koehler's. The study population included Early Childhood Development (ECD) teachers, education officers in charge of ECD in the county and public primary school headteachers. Simple random sampling was used to obtain $177 \mathrm{ECD}$ teachers which is $10 \%$ of $1,768 \mathrm{ECD}$ teachers from 884 public primary schools in Bungoma County. The study adopted a descriptive research design. A questionnaire and interview schedule were the main primary data tools for data collection. The findings showed that Integration of ICT in early education is highly related to teachers' ICT competencies, planning for instruction, teaching methods, teaching and learning materials and how assessment is done. The central issue in the integration of ICT into early learning is pegged on the instructors having the requisite ICT training. ICT integration in early learning is often attributed to the teachers thus, those teachers who competency and higher confidence are expected to integrate ICT in their classes. Teacher's underutilization of ICT in the classroom and their resistance to embedding ICT across the curriculum can be detrimental to attempts to introduce new teaching and learning technologies in education. Therefore, it is crucial to monitor teacher's ICT utilization and examine factors that contribute to their skeptical practices of teaching with technology.
\end{abstract}

Keywords: Integration, Competency, Information Communication Technology

DOI: $10.7176 / \mathrm{JEP} / 11-30-11$

Publication date:October $31^{\text {st }} 2020$

\section{Introduction}

The potential benefits that technology brings to the improvement of overall learning outcomes cannot be overstated especially in the face of increasing evidence from educational researchers that suggests the use of ICT devices enhances the learning experience for young learners significantly (Glaubke, 2007; McCarrick \& Li, 2007). In addition, the evidence also suggests that early exposure to ICTs improves the overall competence of such learners particularly in the job market, therefore, giving them a competitive edge. As such, many learning institutions are increasingly innovating their processes and systems to incorporate technology from the early stages of their learners' development not only because of the advantages it has on their overall learning outcomes, but also because of the competitiveness it offers them in client acquisition and retention (Barron et al., 2011).

However, unlike other forms of traditional teaching methods and materials, getting learners ready for the complexities that learning with ICTs creates requires closer contact between learners and instructors and among the learners themselves in the long term (McManis \& Gunewig, 2012). In addition, it also requires teachers to be more sensitive to the demographic background of their learners because they play an important role in influencing their attitudes and interests (McManis \& Gunewig, 2012). As a result, it is also important that teachers are prepared well in the same because their biases and predispositions often form the basis of their attitudes and interests in different technologies. It also prepares them for the intricate task of creating high impact material for the different groups of learners under their charge, therefore, further increasing learner outcomes (Glaubke, 2007).

The increasing innovations in ICTs is also working to reduce the cost and increase the ease with which learners and their teachers can collaborate and benchmark their performance with other groups from across the globe. Social media, for example, is fast becoming an important platform with a suite of communication tools that let learners leverage the devices they have at their disposal to communicate with each other in real time. However, 
this feature of ICTs is also creating unique problems for teachers as they can also be used in cheating in exams and assignments, therefore, putting the accountability of learning institutions in jeopardy. The increasing integration of multimedia and communication gadgets into a single device, whose sizes is also decreasing by the day, makes technology a double-edged sword in the education sector. It also brings with them a myriad of ethical and legal issues because of the consequences of their use and ownership. This study, therefore, aims to understand teachers' competency in integration of Information Communication Technology in early learning.

\subsection{Statement of the Problem}

There is a growing recognition of the many different ways that ICT can contribute to, or transform, the activities, roles, and relationships experienced by teachers and in early childhood education settings. Bray, M., Brown, M., \& Green, T. (2004) suggests three reasons why ICT matters in early childhood education. First, ICT already has an effect on the people and environments that surround young children's learning. Second, these technologies offer new opportunities to strengthen many aspects of early childhood education practice. Third, there is support and interest across the whole education sector for the development and integration of ICT into education policy, curriculum, and practice.

However, there is a clear consensus in the literature that the introduction and use of ICT in early childhood education should be grounded in a clear understanding of the purposes, practices, and social context of early childhood education. Since literature has show that integrating technology into curricula with the intent of positively influencing teaching and learning has been in a state of evolution, the main purpose of the study is to find out teachers' competency in the integration of Information Communication Technology onto teaching and learning in early learning in Bungoma County, Kenya.

\subsection{Literature Review}

\subsection{Teachers' Competency in Integrating ICT in Early Learning}

The dynamism of the ICT sector coupled with the evolving goals and needs of education functions make technology integration in learning development a long-term project to ensure that the systems remain effective through the changes in the environment out of which they operate. Teachers and learners being the integral pieces of the system need to be able to understand how to leverage the tools these platforms make available to make their work easier and the processes they work with more flexible and efficient. And, because technology operates like the central nervous system, linking the different systems and functions operating in different societies, teaching it in schools promises to help countries improve the wellbeing and productivity of their populations for the increasingly digitized societies and economies of the future (Abbott, Blakeley, Beauchamp, Rhodes, Cox, Webb, 2006).

In fact, if the education system is to remain strategic in building learners' capacity to thrive in the increasingly volatile world in which they live, it is important that policymakers develop structures that empower teachers with the foresight to adopt the material available to suit the prevailing circumstances of their environment. In so doing, they will also be helping their learners to develop contextual situational analysis skills organically, that are useful in helping them build on the knowledge they have acquired by testing it in new scenarios and environments. As a result, it should also help them to spur the evolution of learners into active change agents in learning processes by empowering them with the capacity to ask thought provoking questions that challenge the status quo and advise the improvement of course material.

According to Boyd (2003), the advantages that technologies bring to any process or function should be apparent enough today given the numerous studies and information available on the subject. As a result, he concludes that any scepticism can only be the result of ignorance on the part of the sceptic or disdain for the process or technology in general. All sectors and functions that have introduced technology tools into their systems and processes have recorded efficiencies, some of which they had not and could not have forecasted because of how they work to enhance the abilities of their users. As such, it stands to reason that while their use in the classroom should increase the outcomes in learning outcomes significantly, it also has the potential of helping learners and their institutions to discover and develop platforms and tools that make them a lot of money, or make their environments more comfortable and safer. Many Silicon Valley tech companies are a great example of that last point.

However, the initiative can benefit from more research into the specific interactions between ICTs and early child education programs because most of the existing literature focuses on the advanced stages of learning development predominantly (Bayhan, Olgun, and Yelland, 2002). The major concern among educators revolve around the antisocial behaviors that technologies are fast creating that contradicts one of the pillars of their service, the socialization of children. Without understanding how to interact with others, children will grow into selfish individuals that can neither learn from others, nor respect divergent views.

Also, too much reliance on tools reduces learners' ability to develop the mental capacity and fortitude to solve complex problems and challenges that require higher contextual reasoning (Cetingul \& Dulger, 2006). As a result, 
it is important that policymakers and strategists develop frameworks that strive to strike a balance between the social and the cognitive development of their learners. Also, starting learners out early enough in their education journey promises to improve their ability to make their learning development and experience more holistic by helping them to understand the importance of both these aspects in their overall growth and development.

Despite the ongoing developments in education reforms across the globe, the integration of technology is still slow and faced with a myriad of challenges, institutions and nations can increase their overall effectiveness by developing strategies to improve the capacity of their teachers actively (Du, Havard, Yu, \& Adams, 2004). As a result, they should encourage higher outcomes from the increase in positive attitudes among both teachers and learners that work to encourage uptake and support and generate a lot of actionable feedback that should help in improving the overall success of learning programs and facilities.

\subsection{Factors influencing teachers' adoption and integration of ICT}

ICT integration is a complex process because of the uncertainties arising from the interplay between the different systems involved and their users that create unforeseeable and unprecedented reactions more often than not (Rangaswamy \& Gupta, 2000). As a result, adoption has continued to plague policymakers over the years because of the influence it has over both encouraging higher investment in novel ideas, and in fostering higher acceptance and support among users (Rogers, 2003). The low adoption rates among instructors further limits the proliferation of technology in education because of how it influences their perceptions, and in turn that of their learners.

The success of ICT integration, therefore, relies on the ability of education strategies and structures to achieve an optimal mix of process integrity and the elements/ resources that are necessary for the effectiveness of learning development programs (Earle, 2002). The former works to ensure that the quality of content increases learning outcomes while the former works to ensure that the delivery mechanism for knowledge enhances the continuity of the learning process (Williams, 2003). The tools that technology provides can only be effective if the underlying structures handling delivery are robust enough to handle the learning development holistically. Otherwise, institutions and systems risk losing significant amounts of money and time developing interventions that have little ROI and that are not sustainable in the long term. Also, because of the tailspin effect that the resulting confusion causes, the losses from the disruption in the continuity of learning processes further reduce overall learning outcomes and affect stakeholder perceptions negatively.

Studies have established that the elements involved in ICT integration in the classroom can be divided into three major categories depending on the level of system users they affect or with whom they interact (Rogers, 2003; Stockdill and Moreshouse, 1992). First, teacher level aspects refer to the elements involved in advising teachers' proficiency in the use of technology both in their lives and in teaching because of the influence this has on their overall attitudes towards technology tools (Balanskat, Blamire \& Kefalla, 2007). Second, school level aspects refer to the ability of institutions to provide adequate technology tools (computers and learning programs and platforms) for use in the classrooms (Chen, 2008, Tondeur; van Braak \& Valcke, 2008).

The main issues teachers have raised through the years on how to strengthen the integration of technology in the classroom surround developing training programs that increase teachers' understanding of the uses and implications of technology tools in their personal and professional lives (Peralta \& Costa, 2007). There is a lot of evidence that suggests that teachers with greater control over the content they teach, as a result of understanding it more intimately, have the confidence to deliver it more emphatically and with higher outcomes than their counterparts who do not understand their content that much (Jones, 2004).

Attitudes also affect the level of adoption of ICTs between male and female teachers, with the former showing more propensity towards the acquisition and use of gadgets than the latter (Volman \& van Eck, 2001). As such, female teachers are also less likely to pursue computer related trainings or look to integrate ICT tools into their content delivery processes or in their lesson preparation processes (Kay, 2006; Wozney et al., 2006). And, since female teachers and ten time more likely to go into early childhood education, particularly in developing parts of the world, it presents a present challenge to the full realization of technology integration in the classroom at the formative levels (Markauskaite, 2006). Female teachers are more predisposed to the traditional setup and definitions of the learning environment and experience and prefer to have more direct contact with their learners and the content they deliver (Burnett, Finger and Watson, 2006). However, female teachers are also more likely to use technology in their processes and in the classroom more effectively in the long term because they are more flexible to change and adopt to the evolution of technology more efficiently as evidenced in studies in elementary schools in the US (Breisser, 2006).

In the long term, however, the effects of gender on the adoption and integration of technology in the classroom is less pronounced, particularly as the ownership and use of the tools that technology develops becomes more widespread (Adams, 2002; Yukselturk and Bulut, 2009). In fact, studies show that female users are more prolific and diverse in how they employ these tools to make their work easier and to improve the efficiency of the systems of which they are a part than their male counterparts (Kay, 2006; Norris, Sullivan, Poirot \& Soloway, 2003). Therefore, this evidence suggests that creating frameworks that promote higher ICT skills development should 
increase the reduction of the gaps between the attitudes that are apparent in male and female users, and improve their adoption and acceptance of their use in the classroom.

\subsection{Research Methodology}

This thesis used a descriptive research design as it allowed the researcher to analyze in detail a single person / case to gain insight into early years learning and teaching. Comprehension of the philosophical paradigm underlying the analysis is very critical and this study adopts a pragmatic framework. The study was conducted in Bungoma County, three counties are bordering it namely: Kakamega in the South, Trans Nzoia in the North, and Busia in the West. It also enjoys a wide shared international border with Republic of Uganda. The study was guided by Technological Pedagogical Content Knowledge Framework (TPACK) by Punya Mishra and Matthew J. Koehler's. The study population included Early Childhood Development (ECD) teachers, education officers in charge of ECD in the county and public primary school headteachers.

Simple random sampling was used to obtain 177 ECD teachers which is $10 \%$ of 1,768 ECD teachers from 884 public primary schools in Bungoma County. This study also used cluster sampling to cluster the 9 sub-counties in Bungoma county. Each sub-county has one ECD education officer and therefore, the study sampled all the 9 officers. Simple random sampling was also used to obtain 9 headteachers, one from each cluster for the purpose of obtaining detailed data from the interviews.

The study adopted a descriptive research design. Self-regulated questionnaires and semi-structured interviews were the main tools of data collection. Using triangulation, the researcher was able to capture a more thorough, holistic and contextual representation and reveal the different dimensions of the phenomena under study. Bias was minimized and validity improved with the use of triangulation. The selection of these tools depended on the nature of the data to be collected, the time for the study, and the study goals. Quantitative data were analyzed using descriptive statistics and presented in both graphical and tabular formats while qualitative data were analysed using thematic analysis.

\subsection{Findings and Discussion}

This section presents the findings of the study based on the data obtained from the respondents. The purpose of this mixed method study was to find out teachers' competency in the integration of Information Communication Technology onto teaching and learning in early learning in Bungoma County, Kenya. Data collection was done using triangulation of two tools; questionnaires for ECD teachers and interview schedule for headteachers and ECD education officers. The study managed to capture data from 104 ECD teachers representing about $90 \%$ of the sample size.

\subsection{Teachers' Competency in Integrating ICT in Early Learning}

The study sought to identify the characteristics of the information communication technology resources i) being accessed, ii) their usage frequency, iii) perceptions and satisfaction levels. The study adopted these features based on the notion that it would help in defining the attributes of the integration of information technology into early learning in Bungoma county. The results were reported in frequencies and percentages and aided in interpreting descriptive results of the study. 
Table 4.1: Teachers' Competency in Integrating ICT in Early Learning

\begin{tabular}{|c|c|c|c|}
\hline Variable & Categories & $\mathbf{N}$ & $\%$ \\
\hline \multirow[t]{3}{*}{ ICT training } & Yes & 55 & 31.0 \\
\hline & No & 122 & 69.0 \\
\hline & Total & 177 & 100.0 \\
\hline Basic computer literacy & Advanced & 14 & 7.9 \\
\hline \multirow[t]{4}{*}{ levels } & Intermediate & 47 & 26.6 \\
\hline & Basic & 94 & 53.1 \\
\hline & None & 22 & 12.4 \\
\hline & Total & 177 & 100.0 \\
\hline \multirow[t]{3}{*}{ Computer ownership } & Yes & 10 & 5.6 \\
\hline & No & 167 & 94.4 \\
\hline & Total & 177 & 100.0 \\
\hline \multirow[t]{3}{*}{ Computers in schools } & Yes & 56 & 31.6 \\
\hline & No & 121 & 68.4 \\
\hline & Total & 177 & 100.0 \\
\hline Computer access and & Frequently & 5 & 2.8 \\
\hline \multirow[t]{4}{*}{ usage at school } & Occasionally & 21 & 11.9 \\
\hline & Rarely & 30 & 16.9 \\
\hline & Never & 121 & 68.4 \\
\hline & Total & 177 & 100.0 \\
\hline \multirow{5}{*}{$\begin{array}{l}\text { Changes in the role of the } \\
\text { teacher }\end{array}$} & Very much & 21 & 11.9 \\
\hline & Somehow & 35 & 19.8 \\
\hline & Partially & 51 & 28.8 \\
\hline & Not at all & 70 & 39.5 \\
\hline & Total & 177 & 100.0 \\
\hline \multirow{3}{*}{$\begin{array}{l}\text { Does ICT make your work } \\
\text { easier? }\end{array}$} & Yes & 104 & 58.8 \\
\hline & No & 73 & 41.2 \\
\hline & Total & 177 & 100.0 \\
\hline The usefulness of ICT in & Content generation (Useful) & 132 & 74.6 \\
\hline \multirow{7}{*}{ learning/teaching } & (Not useful) & 45 & 25.4 \\
\hline & Instruction planning (Useful) & 147 & 83.1 \\
\hline & (Not useful) & 30 & 16.9 \\
\hline & Content management (Useful)(Not useful) & 112 & 63.3 \\
\hline & & 65 & 36.7 \\
\hline & Classroom management (Useful) & 128 & 72.3 \\
\hline & (Not useful) & 49 & 27.7 \\
\hline
\end{tabular}

Source: Research Data (2019)

From the study, majority of the respondents $69.0 \%(122)$ of the have not undergone training in ICT training while the remaining 31.0\%(55) have undergone ICT training in the past two years. Their basic computer literacy levels showed that $7.9 \%(14)$ had advanced skills in the usage of computers, $26.6 \%(47)$ had an intermediate level, $53.1 \%(94)$ had basic skills for operating computers with the remaining 12.4\%(22) having little or no skills in computer usage. Lack of technology training of teachers (Dvorak and Buchanan 2002) have also been cited as barriers to technology integration into classroom instruction. Other contextual factors to explain teachers' competence in ICT include computer literacy level whereby this study shows majority of ECD teachers $53.1 \%$ in Bungoma county have basic computer literacy. However, the study indicate that many of the teachers don't own computers and also majority of the schools don't have computers hence computer access and usage of by ECD teachers in Bungoma county is minimal.

Head Teachers and ECD Education Officers in Bungoma also agreed that they have not trained ECD teachers for the integration of ICT in teaching and learning in the last two years. In fact, interviews revealed that most schools do not have computers, printers or other ICT devices, and therefore teachers do not have knowledge and ability to control ICT devices. Jones (2004) reported that the performance of teachers is directly related to trust. Teachers' trust often relates to their expectations of their abilities to use computers in classrooms, especially in relation to the perceived skill of their students.

However, if more equipment or training is to be provided to teachers, this support must also recognize the views and beliefs of teachers about children's learning and development and place them at the forefront of ICT support and the provision of professional development for the sector. Most current ICT research in early childhood education takes a "positive" view of teachers, who find teachers to be educators with a critical role in decision- 
making and to promote young children's ICT interactions, which therefore require support in developing ICT capabilities and literacy. Developing the capacity of ICT teachers and literacy does not simply mean providing them with the skills to use different forms of ICT. It also means providing teachers with opportunities to learn more about the opportunities ICT offers for new ways of communicating, seeking and managing information, and interacting with the environment and others; what research shows about the role and impact of ICT use in children's learning, play and development; and examples of how other early childhood education settings have been used. Developing the capacity of ICT teachers and ICT literacy also means providing them with opportunities to identify how ICT can be used to support or extend their practice in their own early childhood education setting (Downes \& Fatouros, 1995).

Cummings, Phillips, Lake, Lowe, Lee (2010) studies, there are also legitimate concerns about Internet use. Students who can freely use computers to access the Internet may be exposed to offensive or inappropriate information that is not appropriate for their age. It is also important for educators to be able to distinguish whether students want technology to be used or whether they prefer the use of traditional teaching materials.

With regard to the role of ICT in teacher roles, $11.9 \%$ (21) of teachers admitted that ICT changes the role of teachers in a large way. $19.8 \%$ (35) indicated that somehow and $28.8 \%$ (51) said that ICT partially changed the role of the teacher. However, 39.5 per cent (70) of the teachers indicated that ICT does not change the role of the teacher. However, Ozgur \& Seyhan, 2010) suggests that the need to change the role of teachers is irreversible and inevitable because, together with the introduction of ICT into schools, certain educational assets have become obsolete. It is the responsibility of the teacher to adapt both themselves and the learners, as well as the lessons to the new technologies and possibilities it offers. It is no longer sufficient for teachers to be the only educational authority to transfer knowledge to the learners. Teachers must encourage critical thinking skills, promote information literacy and support collaborative work in order to prepare students for the 21 st century. In addition, the identification, grouping and confirmation of electronic data sources should be one of the main tasks for educators.

Past studies have further elaborated on the positive developments in the use of computers by teachers in the classroom. Thus, depending on the country and type of school, there are different levels of competence and skills among teachers to use computers in the classroom (Korte \& Hüsing, 2006).

When the respondents were asked whether ICT makes their work easier, majority of 58.8\%(104) admitted that ICT makes their work easier. In addition, concerning the usefulness of integrating ICT in teaching and learning in early years, $74.6 \%(132)$ of the respondent affirmed that ICT is useful in content generation, $83.1 \%(147)$ confirmed that ICT is useful in instructional planning, $63.3 \%(112)$ of the respondent said ICT is useful in content management and $72.3 \%(128)$ of the teachers informed that ICT is useful in classroom management. Empirical results indicate that teachers used computers most often for preparing tests and course handouts and preparing homework assignments, grading and performing administrative tasks. Very few teachers reportedly used for instructional software to enhance their classroom teaching (Yildirim, 2014).

The findings indicate that ICT is very relevant and has a number of benefits when integrated into early learning. As a result of the study, the integration of ICT into teaching is beneficial to children's learning and development. These benefits are reflected in many aspects, including language and emerging literacy, mathematical thinking, creativity, problem-solving, personality, communication and collaboration, as well as positive attitudes towards learning (Umayahara, 2014). On the other hand, some researchers are also discouraging the integration of ICT in early childhood teaching, especially for very young children.

The literature suggests that there is a clear potential for ICT use, including computers, to enrich the early childhood learning environment. Technology adds to the set of tools available to children to be used and adapted, to feel at home, to be part of their repertoire, and to help them express themselves verbally, visually and emotionally. New technologies provide additional resources for teachers to use as they plan to meet a range of levels, learning styles and learners' individual needs (Van Scoter \& Boss, 2002). Like any educational resource, new technologies can be used well or badly (Siraj-Blatchford \& Whitebread, 2003). The value that ICT can add to the learning environment of young children clearly depends on the choices that teachers make about which tools to choose and when and how to use them; and on their understanding of how these tools can support children's learning, development, participation or play.

Interviews with ECD Education Officers and Head Teachers revealed some challenges that affect the integration of ICT into early learning in Bungoma County. The majority of respondents pointed out the following challenges: limited training opportunities for teachers in the use of ICT; insufficient equipment or resources to purchase equipment; lack of on-site technical support; or lack of time to develop ICT-integrated teaching or learning activities. However, if more time, equipment or training is to be provided to teachers, this support must also recognize the views and beliefs of teachers about children's learning and development and place them at the forefront of ICT support and the provision of professional development for the sector. Most current ICT research in early childhood education takes a "positive" view of teachers, who find teachers to be educators with a vital position in decision-making and to promote young children's ICT interactions, and also require help in improving 
ICT skills and literacy. Developing the capacity of ICT teachers and literacy does not simply mean providing them with the skills to use different forms of ICT (O'Hara, 2004).

This also includes presenting teachers with resources to know more about the possibilities ICT provides for innovative forms of communication, finding and handling knowledge, and engaging with the community and others; what evidence indicates regarding the role and effect of ICT usage in children's learning, play and development; and examples of how other early childhood education environments have been utilized. Developing the potential of ICT teachers and ICT comprehension often requires supplying them with resources to understand whether ICT can be used to help or expand their work in their own early childhood education environment (Downes \& Fatouros, 1995).

\subsection{Conclusion and Recommendations}

The key issue in the integration of ICT into early learning is that instructors have the required ICT training. The results showed that most of the ECD teachers in the county of Bungoma did not receive ICT training in the last two years and had basic computer skills. The majority of ECD teachers in the county of Bungoma did not own computer devices, and very few schools have computers for ECD instructors. This justifies the reason why the majority of ECD teachers in the county of Bungoma had limited access to devices and therefore had little or no basic skills for operating computers and other ICT devices.

With regard to the use of ICT in teaching roles, the majority of teachers indicated that ICT does not change the role of teachers in the classroom. However, those respondents who use ICT have admitted that ICT makes their work easier. The findings also indicated that ICT is very relevant and has a number of benefits when integrated into early learning. The advantages outlined include; devices improve the early childhood learning environment; technology contributes to the variety of opportunities accessible for children to utilize to better articulate themselves; and emerging innovations include unique options for instructors to leverage while they prepare to address a spectrum of learning preferences and learners' specific needs. Respondents pointed out the following challenges regarding the ICT integration into early learning: training opportunities that were inadequate for teachers in the use of ICT; infrastructure insufficiency or funds for purchase equipment; lack of on-site technical support; lack of the time to develop ICT-integrated teaching or learning programs.

From the study results it is concluded that teachers undergo adequate training about how to use the Technology in teaching and learning processes to gain the requisite knowledge and skills to incorporate technology into classrooms. This will provide teachers with the resources to promote student-centred learning. Teachers should also be educated in the basic instructional use of technology rather than the general use of computers. In addition, instruction should be offered on the use of ICT applications other than basic word processing.

Based on the findings, the study recommends that teachers should be provided with in-service training on how to use different technology applications, devices and approaches to managing technology in the classroom. Finally, the ministry of education together with the county government to recognizing the critical role of technology in teaching and learning. Provision and facilitation of ICT training and induction of educational software training for instructors in order to improve their ICT capabilities and usage. This can be achieved through regular seminars and workshop training on the type of educational software and the appropriate devices.

\section{REFERENCES}

Abbott, C., Blakeley, B., Beauchamp, T., Rhodes, V., Cox, M., \& Webb, M. (2006). ICT and pedagogy - a review of the research literature. Becta.

Barron, B., Cayton-Hodges, G., Bofferding, L., Copple, C., Darling-Hammond, L., \& Levine, M.H. (2011). Take a Giant Step: A Blueprint for Teaching Young Children in a Digital Age. New York: Joan Ganz Cooney Center at Sesame Workshop. www.joanganzcooneycenter.org/Reports-31.html

Bayhan, P., Olgun, P., \& Yelland, N. J. (2002). A study of pre-school teachers thoughts about computer-assisted instruction. Contemporary Issues in Early Childhood, 3(2),

Boyd, D. (2013). The impact of information communication technology on learner achievement. URL http://blogs.ubc.ca/boydetec590/files/2012/02/Boyd-Final-Draft-5112.pdf

Bray, M., Brown, M., \& Green, T. (2004). Technology and the diverse learner: A guide to classroom practice. Thousand Oaks, California: Corwin Press.

Brooker, L., \& Siraj-Blatchford, J. (2002). 'Click on miaow!': how children of three and four years experience the nursery computer. Contemporary Issues in Early Childhood: Technology Special Issue, 3 (2), 251-273. Also available at http://www.ioe.ac.uk/cdl/CHAT/pdfs/click.pdf

Çetingül, P.I. T., \& Dülger, I. 82006). ÖSS başarı durumunun il, bölge ve okul türlerine gore analizi [Analysis of the ÖSS results according to school types, cities, and regions in Turkey]. Eğitim ve Bilim, 31(142), 45-55.

Chen, B., \& Bryer, T. (2012). Investigating instructional strategies for using social media in formal and informal learning. The International Review of Research in Open and Distributed Learning, 13(1), 87-104.

Downes, T., \& Fatouros, C. (1995). Young children learning in their preschool and primary years: A framework 
for planning to incorporate IT. Australian Educational Computing, May, 4-9.

Du, J. X., Havard. B., Yu, C. \& Adams, J. (2004). The impact of technology use on low-income learners' academic achievements: Educational Longitudinal Study of 2002. Journal of Educational Research and Policy Studies, 4(2), 21-28.

Dvorak, J., \& Buchanan, K. (2002) Using technology to create and enhance collaborative learning. (ERIC Document Reproduction Service No. EJ 477001)

Glaubke, C. R. (2007). The Effects of interactive media on preschoolers' learning: A review of the research and recommendations for the future. Oakland, CA: Children Now

Jones Diaz (Eds.), (2004) Literacies in early childhood: Changing views, challenging practice (pp. 269-287). Eastgardens, N.S.W.: MacLennan and Petty

Korte, W. B., \& Hüsing, T. (2006). Benchmarking access and use of ICT in European schools 2006: Results from head teacher and a classroom teacher surveys in 27 European countries. empirica, 1(0).

Lowe, K., Lee, L., Schibeci, R., Cummings, R., Phillips, R., \& Lake, D. (2010). Learning objects and engagement of learners in Australian and New Zealand schools. British Journal of Educational Technology, 41(2), 227241.

McCarrick, K., \& Li, X. (2007). Buried treasure: The impact of computer use on young children's social, cognitive, language development and motivation. AACE, 15(1), 73-95

McManis, L. D., \& Gunnewig, S. B. (2012). Finding the education in educational technology with early learners. Young Children, 67(3), 14.

Ozgur, E., Güler, G., \& Seyhan, N. (2010). Mobile phone radiation-induced free radical damage in the liver is inhibited by the antioxidants n-acetyl cysteine and epigallocatechin-gallate. Int. J. Radiat. Biol. 2010, 86, 935-945

Schibeci, R., Cummings, R., Phillips, R., Lake, D., Lowe, K., \& Lee, L. (2010). Learning objects and engagement of learners in Australian and New Zealand schools. British Journal of Educational Technology, 41(2):227241.

Siraj-Blatchford, I., \& Siraj-Blatchford, J. (2003). More than computers: Information and communication technology in the early years. London: The British Association for Early Childhood Education.

Siraj-Blatchford, J., \& Whitebread, D. (2003) Supporting information and communications technology education in early childhood, Buckingham: Open University Press.

Umayahara, M. (2014). Benefits and risks of ICT use in early childhood. Resource document. Accessed, $20^{\text {th }} \mathrm{June}$ $2005 \quad h t t p: / / w w w$. unescobkk.org/education/ict/onlineresources/databases/ict-in-educationdatabase/item/article/benefits-and-risks-of-ict-use-in-early-childhood/. 